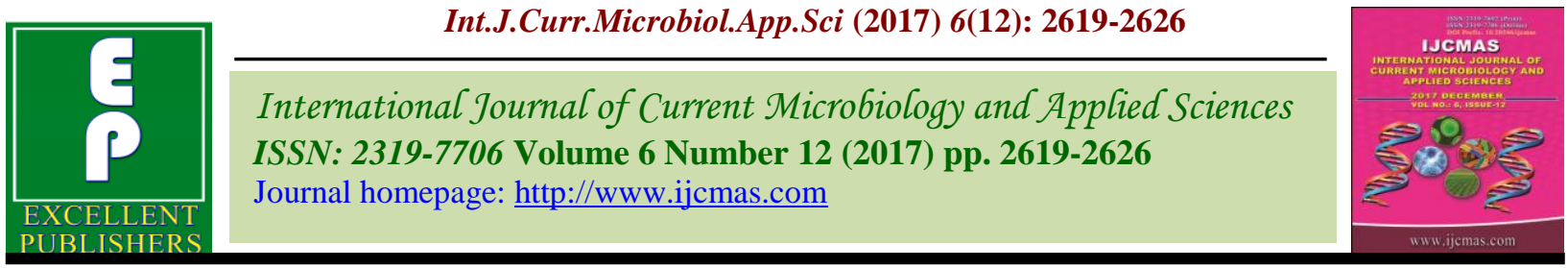

Review Article

https://doi.org/10.20546/ijcmas.2017.612.303

\title{
Apomixis: A Boon to Plant Breeding
}

\author{
Khushboo Chandra* and Anil Pandey \\ Department of Plant Breeding and Genetics, Dr. Rajendra Prasad Central \\ Agricultural University Pusa, Samastipur, Bihar, India \\ *Corresponding author
}

\begin{abstract}
A B S T R A C T
Apomixis is a method of asexual reproduction in plants i.e., seed formation without fertilization with three main variants, viz., apospory, diplospory, and adventitious embryony. Genetic understanding of apomixis has been handicapped for a long time due to

Keywords

Apomixis,

Parthenogenesis, Vybrids.

Article Info

Accepted:

19 October 2017

Available Online:

10 December 2017

lack of techniques viz., for isolation of embryo sacs, use of flow cytometry, and availability of molecular markers for a rapid and accurate identification of apomictic genotypes (Crane and Carman, 1987; Peel, 1993). Apomixis is a consequence of deregulation of the genes involved in sexual reproduction. Harnessing apomixis is a major goal in applied plant genetic engineering. In this regard, efforts are focused on genetic and breeding strategies in various plant species, combined with molecular methods to analyze apomictic and sexual modes of reproduction and to identify key regulatory genes and mechanisms underlying these processes. These can open new avenues for the transfer of the apomixis trait to important crop species and will have far-reaching potentials in crop improvement regarding agricultural production and the quality of the products. This review paper contains an idea about apomixes, types, genes involved in genetic and molecular basis of apomixis and role in crop improvement. Therefore, it seems that apomixis is about to change the face of plant breeding forever.
\end{abstract}

\section{Introduction}

Apomixis $($ apo $=$ detached $/$ separate; mixis $=$ union/combination) term introduced in 1908 by Winkler, seeds are formed but the embryos develop without fertilization (Nogler, 1984). When sexual reproduction does occur, the apomixis is termed as 'Facultative', exBlue grass, Pearl millet and Sorghum.

When sexual reproduction is absent, it is referred to as 'Obligate', ex- Panicum maximum. Apomixis is usually found at a higher ploidy level. Apomixis is a complex and coordinately regulated cascades of events controlled by one or a few genes (Savidan
2000). Apomixes is controlled by large sectors of DNA in which recombination is suppressed (Bicknell et al., 2000).

\section{Apomixis deviates from sexual reproduction in following aspects (Ramulu et al., 1998)}

Modification or complete omission of meiosis.

Formation of unreduced megaspore.

Parthenogenetic development of embryo. 
Autonomous or pseudogamous endosperm development.

Three developmental components of apomixes (Naumova, 1993)

\section{Apomeiosis}

Imperfect or suppressed meiosis, a characteristic of the life cycle of many higher polyploids.

\section{Parthenogenesis}

A type of asexual reproduction in which a female gamete or egg cell develops into an individual without fertilization.

\section{Pseudo apomixis or autonomous apomixes}

Apomixis requires fertilization to produce the endosperm of the seed.

\section{Conversion of apomictic plant}

Three ways to convert sexual crops into apomictic plant

Wide crosses with apomictic wild relatives

Mutation

Genetic transformation.

\section{Types of apomixis}

Two types of apomixis (Stebbins, 1950)

\section{Sporophytic}

A sporophyte is the diploid multicellular stage in the life cycle of a plant. It develops from the zygote produced when a haploid egg cell is fertilized by a haploid sperm and each sporophyte cell therefore has a double set of chromosomes, one set from each parent.

\section{Types of sporophytic (Bashaw, 1980)}

\section{Adventive embryony}

Also called sporophytic apomixis, sporophytic budding, or nucellar embryony, megagametophyte in the ovule, but the embryos do not arise from the cells of the gametophyte; they arise from cells of nucellus or the integument. e.g., citrus, mango, jamun etc.

\section{Parthenogenesis}

Asexual reproduction in which growth and development of embryos occur without fertilization.

\section{Haploid parthenogenesis}

The haploid eggs are not fertilised by the male gamete and develop into the haploid individuals.

\section{e.g., Solanum nigrum, Nicotiana and Maize}

\section{Diploid parthenogenesis}

In the diploid parthenogenesis, the embryo develop from the unfertilized diploid eggs

e.g., Grasses like Taraxacum

\section{Apogamy}

The asexual development of a sporophyte from a cell or cells of the gametophyte other than the egg.

e.g., Allium sps.

\section{Gametophytic}

Apomixis where the maternal seed embryo develops from the egg cell of a welldeveloped embryo sac, without fertilization. 
Types of gametophytic (Bashaw, 1980)

\section{Apospory}

Apospory is the development of $2 \mathrm{n}$ gametophytes, without meiosis and spores, from vegetative, or nonreproductive, cells of the sporophyte.

e.g., Malus, Crepis, Paspalum, Pennisetum, Poaceae, Ranunculus, Sorghum

\section{Diplospory}

Diplospory is an apomeiotic pathway where a diploid embryo sac develops from an unreduced megaspore mother cell. e.g., Ixeris, Antennaria Tripsacum, Eragrostis, and Taraxacum

Embryo sac development in apomictic plant

There are seven types of diplosporic embryosac development

Taraxacum type: Genera of Compositae and in Arabis and Paspalum species.

Ixeris type

Antennaria type

Allium type: Allium species

Blumea type

Elymus type: Elymus rectisetus

Eragrostis type

There are two types of aposporic embryosac development

Hieracium type

Panicum type
Genetic basis of apomixis are involved in shaping the apomictic phenotype (Ortiz et al., 2013)

Termination of meiosis.

Formation of aposporous embryo sacs and their parthenogenetic development

Sporophytic and Gametophytic factors

Modify gene expression

Segregation distortion

Suppressed recombination and environmental effects

Presence of asymmetric genome regions

Techniques for isolation of apomictic plant (Spillane et al., 2004)

There are five types of techniques for isolation of apomictic plant:

\section{Morphological}

Uniformity of progeny from heterozygous or cross-pollinated parents. Occurrence of maternal phenotypes in crosses

\section{Cytological}

Cytological analysis of developing embryo sac is made at different stages from initiation of MMC to the formation of mature embryo sac.

\section{Histological}

Female florets at different stages of maturity are collected. Fixed in FAA for $24 \mathrm{~h}$ and are then transferred to $70 \%$ ethanol. Pistils are dissected and dehydrated using the ovule clearing method. 
Fig.1 Normal double fertilization
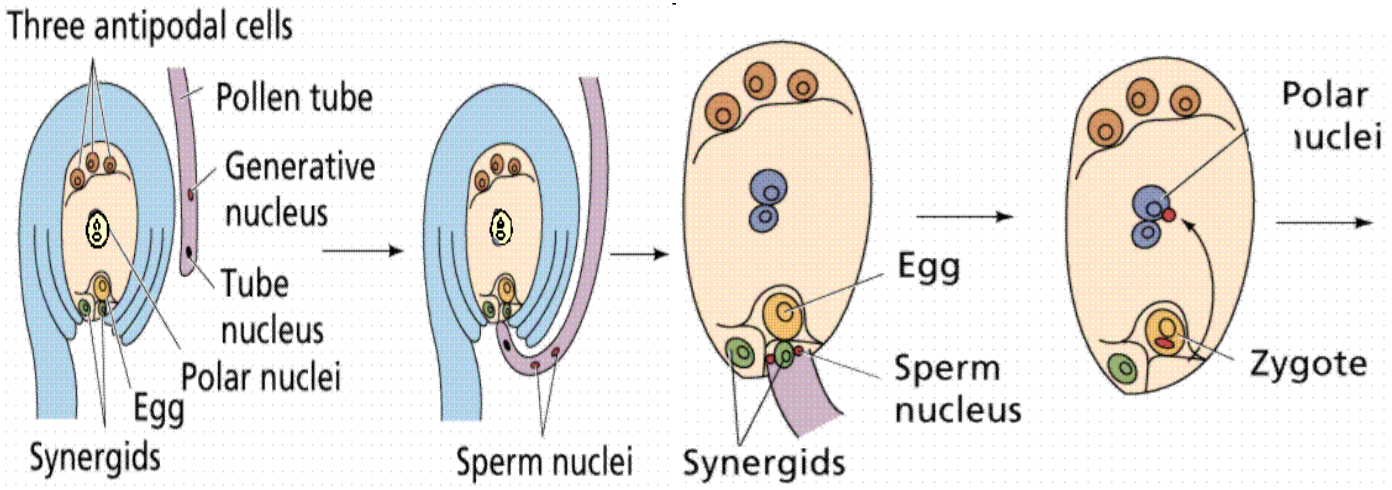

Fig.2 Initiation and progression of apomictic mechanisms relative to events in the sexual life cycle of angiosperms

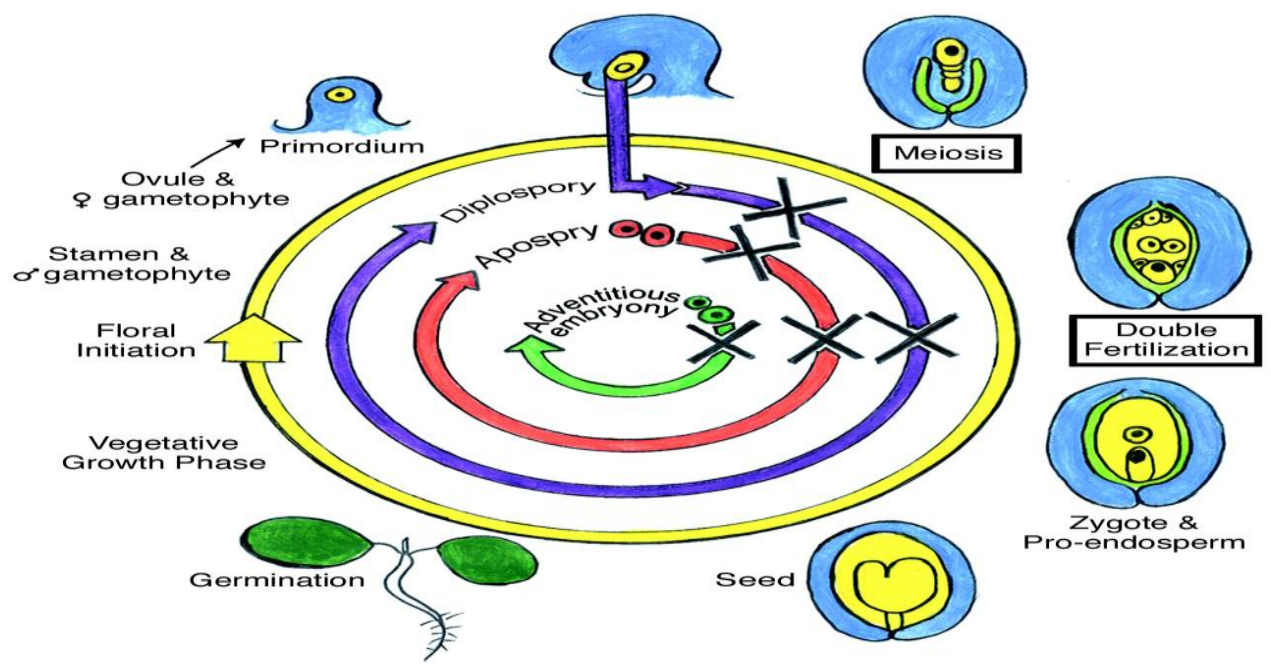

Table.1 A brief overview of the genetic basis of different types of apomixes

\begin{tabular}{|l|l|l|l|}
\hline Species & Type of apomixis & No. of loci & Genome \\
\hline Brachiaria & Apospory,Parthenogenesis & $\mathbf{1}$ & Aaaa \\
\hline Cenchurus & Apospory,Parthenogenesis & $\mathbf{1}$ & Aaaa;++ \\
\hline Erigeron & Diplospory & 2 & D/dd;+Fff \\
\hline Hieracium & Apospory,Parthenogenesis & $\mathbf{2}$ & Aaaa,Pppp;+ \\
\hline Panicum & Apospory & $\mathbf{1}$ & Aaaa;++ \\
\hline Paspalum & Apospory,Parthenogenesis & $\mathbf{1}$ & Aaaa;+ \\
\hline Paspalum & Apospory,Parthenogenesis & $\mathbf{1}$ & Aaaa;+ \\
\hline Pennisetum & Apospory,Parthenogenesis & $\mathbf{1}$ & Aaaa;++ \\
\hline Poa & Apospory & $\mathbf{2}$ & Aaaa,Pppp \\
\hline Ranunculus & Apospory,Parthenogenesis & $\mathbf{1}$ & Aaaa \\
\hline Taraxacum & Diplospory & $\mathbf{3}$ & Ddd,Ppp;+ \\
\hline Tripsacum & Diplospory & 1 & Dddd;+ \\
\hline
\end{tabular}


Table.2 A brief overview of the molecular basis of different types of apomixes

\begin{tabular}{|l|l|l|l|}
\hline Species & Endosperm development & Candidate genes & Reference \\
\hline Brachiaria & Pseudogamous & RPS8-RPS1a-RPL41 & $\begin{array}{l}\text { Lacerda } \text { et al., } \\
2013\end{array}$ \\
\hline C. Ciliaris & Pseudogamous & BMM-like & $\begin{array}{l}\text { Conner } \text { et al., } \\
2008\end{array}$ \\
\hline Heiracium spp. & Autonomous & HFIE & $\begin{array}{l}\text { Rodrigues } \text { et al., } \\
2008\end{array}$ \\
\hline Heiracium performatum & Pseudogamous & HAPPY locus & Galla et al., 2010 \\
\hline Pennisetum notatum & Pseudogamous & LORELE1 & Felitti et al., 2011 \\
\hline Boechera & Pseudogamous & APOLLO & Corral et al., 2013 \\
\hline
\end{tabular}

Table.3 Current research on apomixes

\begin{tabular}{|l|l|l|}
\hline APOMICTIC SPECIES & ORGANIZATION & LOCATION \\
\hline WHEAT & Institute of Plant Genetics & Germany \\
\hline Hieracium & C\&FR & New Zealand \\
\hline Evolution of apomicts & Utah State University & Logan, USA \\
\hline Histology of apomixis & Jagellonian University & Poland \\
\hline Taraxacum & NIOO & Netherlands \\
\hline Pennisetum & USDA -ARS & Tifton, USA \\
\hline Molecular tools for apomixis & CAMBIA & Australia \\
\hline Allium & Kyusu National Agricultural experimental staion & Japan \\
\hline Rice & Academia Sinica & China \\
\hline Hieracium & CSIRO & Adelaid, Australia \\
\hline Pennisetum & University of Georgia & Tifton, USA \\
\hline Paspalum & IBONE & Argentina \\
\hline Tripsacum dactyloides & CIMMYT & Mexico \\
\hline Brachiaria & CIAT & Coloumbia \\
\hline Somatic Embryogenesis & Wageningen Agricultural University & Netherlands \\
\hline Cassava & University of Brasilia & USA \\
\hline Arabidopsis Mutagensis & CSIRO & Australia \\
\hline
\end{tabular}

The pistils are embedded in parafilm, sectioned at $10 \mathrm{~mm}$ and stained with safranin O-fast green.

\section{Biochemical}

Isozyme markers can be used to study genetic variation and to detect the presence of apomixis. The apomictic breeding behaviour was detected in Arabis holboelli and Allium tuberosum through enzyme electrophoresis.
Molecular

If the genes for apomixis can be tagged with molecular markers such as RAPD, RFLP or AFLPs, breeding material can be screened for apomixis.

Two molecular markers (UGT 197 and OPC04) were identified while making crosses between two wild species of Pennisetum and sexual Pearl millet. 


\section{Effect of apomixis}

\section{Biodiversity}

Transfer or introduction of apomixis promotes uniformity. Pennisetum olystachion and Pennisetum subangustum (Schmelzer and Renno, 1997).

\section{Mutation}

"Conditional apomixis" approach in which apomictic reproduction is temporarily switched to sexual reproduction (or vice versa) has gained importance. Conditional apomixis can be achieved using special promoters whose expression level is changed by certain chemical mutagens (Spillane et al., 2004).

\section{Polyploidy}

Apomixis arose from asynchronous expression of duplicate sexual reproductive gene sets in hybrid or polyploid genomes. Alleles responsible for apomixis may act as or linked to recessive lethal factors, thus they can only be transferred by a diploid or polyploid gamete (Nogler, 1993; Naumova, 1987 and Vielle-Calzada, 1996).

\section{Application of apomixis}

Fixation of heterosis.

Production of homozygous line

Production of vybrids.

\section{Advantages of apomixis}

Higher multiplication rate of superior genotypes, including hybrids, as clones in form of seed.

Multiply apomictic hybrid seeds forever since they are clones. This will cause enormous reductions in the price for industry and breeding companies and seed costs for farmers' apomictic hybrid seeds. Apomictic hybrids will not need cytoplasmic male sterility and fertility restorer systems, which means much shorter and easier hybrid development procedures

Easy in storage and planting

Suitability for machine planting

Usage of less seed material

Less bearing of diseases with those of propagation by clone (maintaining genetic structure and fixing superior genotypes after crossing).

"Boutique Breeding" approach to develop specific hybrids for microproduction areas (Jefferson, 1994).

Yield increases of $20 \%-50 \%$ can be expected from hybrids in self-pollinating major crops such as rice and wheat (Tester and Langridge, 2010) as a result of apomixis technology.

In self-pollinating crops no need for six or seven selfing generations to make segregating loci homozygous allow the development of new varieties with one cross.

Apomixis for plant breeding will increase the survival of interspecific crosses.

Apomixis is known to facilitate the survival of hybrids from wide species, at least under natural conditions (Bashaw and Hanna, 1990).

Apomixis will allow multiplication of clonal propagation material in the form of seeds in crops such as potato (Spillane et al., 2004) and cassava (Freitas and Nassar, 2013).

\section{Disadvantages}

Apomixis genes could escape into wild relatives and cause genetic erosion 
Gene transfers from apomictic crops to sexual wild relatives, both of which might have the same ploidy level.

\section{Epigenetics and genomic imprinting problems}

The unsuccessful attempts to transfer apomixis to an experimental or crop species through conventional breeding procedures results in phenomenon called genomic imprinting.

\section{Ecological risks}

A dominant apomixis transgene spread through pollen across populations to a related outcrossing species resulting in rapid fixation of genotypes, displacement of sexual siblings and lead to a reduction in the genetic diversity both within a crop and among its close relatives. Apomixis technology is that it may entrench the trend of monocultures in agriculture thus reducing biodiversity.

\section{Future prospects of apomixis}

Ease of multiplying and maintaining elite hybrid genotypes.

Ease of producing high-quality pure seed without isolation.

Possibilities for selection of more closely adapted diverse genotypes are expected for fixation of hybrid vigor and lower the cost of hybrid seed production.

\section{References}

Bashaw EC (1980) Apomixis and its implication in crop improvement. In: Fehr WR, Hadley HH (eds) Hybridization of crop plants. American Society of Agronomy, Madison, pp 4563.
Bicknell RA, Borst NK, Koltunow AM (2000) Monogenic inheritance of apomixis in two Hieracium species with distinct developmental mechanisms. Heredity 84: 228-237

Conner JA, Goel S, Gunawan G, CordonnierPratt MM, Johnson VE, Liang C, Wang H, Pratt LH, Mullet JE, DeBarry J, Yang L, Bennetzen JL, Klein PE, Ozias-Akins P (2008) Sequence analysis of bacterial artificial chromosome clones from the aposporyspecific genomic region of Pennisetum and Cenchrus. Plant Physiology 147: 1396-1411.

Crane CF, Carman JG (1987) Mechanisms of apomixis in Elymus rectisetus from Eastern Australia and New Zealand. Am J Bot 74: 477-496.

Jefferson RA (1994) Apomixis: a social revolution for agriculture? Biotech Dev Monitor. 19:14-16.

Naumova TN (1993) Apomixis in angiosperms: nucellar and integumentary embryony. CRC Press, Boca Raton.

Nogler, G.A. (1984). Genetics of apospory in apomictic Ranunculus auricomus. Springer, Berlin Heidelberg. 92:123-41.

Ortiz, J.P.A., Quarin, C.L., Pessino, S.C., Acuna, C., Martinez, E.J., Espinoza, F., Hojsgaard, D.H., Sartor, M.E., Caceres, M.E., Pupilli, F. (2013). Harnessing apomictic reproduction in grasses: what we have learned from Paspalum. Annual Botany, London. 112: 767-787.

Peel MD (1993) Meiocyte callose in aposporic and diplosporic grasses and in hybrids between bread wheat and Elymus rectisetus. MS thesis, Utah State University Savidan Y (2000) Apomixis: genetics and breeding. Plant Breed Rev 18:13-86.

Ramulu KS, Dijkhuis R Pereira A, Angenent GC, van Lookeren Campagne MM, Dons H (1998) EMS and transposon 
mutagenesis for the isolation of apomictic mutants in plants. In: Jain SM, Brar DS, Ahloowalia BS (eds) Somaclonal variation and induced mutation in crop improvement. Kluwer, Dordrecht, Current plant science and biotechnology in agriculture, 19: 379401.

Schmelzer GH, Renno JF (1997) Genetic variation in the agamic species complex of Pennisetum section Brevivalvula (Poaceae) from West Africa: ploidy levels and isozyme polymorphism. Euphytica, 96: 23-29.
Spillane, C., Steimer, A., Grossnicklaus, U. (2004) Apomixis in agriculture: the quest for clonal seeds. Sex Plant Reproduction. 14: 179-187.

Stebbins, G.L. (1950). Variation and evolution in plants. Columbia University Press, New York.

Vielle-Calzada JP, Nuccio ML, Budiman MA, Thomas TL, Burson BL, Hussey MA, Wing RA (1996) Comparative gene expression in sexual and apomictic ovaries of Pennisetum ciliare (L.) Link. Plant Molecular Biology, 32: 10851092.

\section{How to cite this article:}

Khushboo Chandra and Anil Pandey. 2017. Apomixis: A Boon to Plant Breeding. Int.J.Curr.Microbiol.App.Sci. 6(12): 2619-2626. doi: https://doi.org/10.20546/ijcmas.2017.612.303 